\title{
Membrane adsorber for endotoxin removal
}

\author{
Karina Moita de Almeida ${ }^{1}$, Maiara Maciel Almeida ${ }^{1}$, Fernando Faria Fingola ${ }^{2}$, \\ Helen Conceição Ferraz ${ }^{1, *}$
}

\begin{abstract}
${ }^{1}$ Chemical Engineering Program, Federal University of Rio de Janeiro, Technology Center, Rio de Janeiro, RJ, Brazil ${ }^{2}$ National Institute of Quality Control in Health of the Oswaldo Cruz Foundation, INCQS/FIOCRUZ, Rio de Janeiro, RJ, Brazil
\end{abstract}

\begin{abstract}
The surface of flat-sheet nylon membranes was modified using bisoxirane as the spacer and polyvinyl alcohol as the coating polymer. The amino acid histidine was explored as a ligand for endotoxins, aiming at its application for endotoxin removal from aqueous solutions. Characterization of the membrane adsorber, analysis of the depyrogenation procedures and the evaluation of endotoxin removal efficiency in static mode are discussed. Ligand density of the membranes was around $7 \mathrm{mg} / \mathrm{g}$ dry membrane, allowing removal of up to $65 \%$ of the endotoxins. The performance of the membrane adsorber prepared using nylon coated with polyvinyl alcohol and containing histidine as the ligand proved superior to other membrane adsorbers reported in the literature. The lack of endotoxin adsorption on nylon membranes without histidine confirmed that endotoxin removal was due to the presence of the ligand at the membrane surface. Modified membranes were highly stable, exhibiting a lifespan of approximately thirty months.
\end{abstract}

Uniterms: Endotoxins/removal. Membrane adsorber/performance. Histidine. Poly(vinyl alcohol).

\begin{abstract}
A superfície de membranas planas de nylon foi modificada utilizando-se bisoxirano como espaçador e poli(álcool vinílico) para recobrimento das membranas. $\mathrm{O}$ aminoácido histidina foi utilizado como ligante para endotoxinas, visando à sua aplicação na remoção de endotoxinas a partir de soluções aquosas. São discutidas as etapas de caracterização do adsorvedor com membranas, análise do procedimento de despirogenização e avaliação da eficiência de remoção em modo estático. A densidade de ligantes nas membranas foi em torno de $7 \mathrm{mg} / \mathrm{g}$ membrana (massa seca), permitindo uma remoção de endotoxinas de até $65 \%$. O desempenho das membranas preparadas com nylon e recobertas com poli(álcool vinílico) contendo histidina como ligante foi superior ao de outros adsorvedores com membranas descritos na literatura. A ausência de adsorção de endotoxinas em membranas sem histidina confirma que a remoção das endotoxinas deve-se exclusivamente à presença do ligante na superfície da membrana. As membranas modificadas mostraram-se bastante estáveis, exibindo um tempo de vida superior a 30 dias.
\end{abstract}

Unitermos: Endotoxinas/remoção. Membrana adsorvente/desempenho. Histidina. Poli(álcool vinílico).

\section{INTRODUCTION}

Endotoxins are heat-stable toxins present in the outer cell walls of Gram-negative bacteria. Chemically, endotoxins are lipopolysaccharides (LPS), with a complex structure exhibiting amphiphilic characteristics, consisting of three different regions: a non-polar lipid, called lipid A, a core polysaccharide and a long chain polysaccharide. The lipid A structure is the most conserved moiety of

*Correspondence: H. C. Ferraz. Ilha do Fundão. Cidade Universitária - Rio de Janeiro. Caixa Postal 68502, Brazil. E-mail: helen@peq.coppe.ufrj.br endotoxins and corresponds to the toxic fraction of LPS, participating in the pathogenicity mechanisms of the bacterial cell. The core polysaccharide structure has an inner heptose region and an outer hexose region while the long chain polysaccharide is a surface antigen (O-antigen) which is strain specific (Petsch, Anspach, 2000).

When cell membrane are disrupted, due to cell death or during downstream processing, endotoxins are released into the lysate. Individuals can be contaminated with endotoxins in several different ways; the most important mechanism is through intravenously applied medications, representing one of the major problems in the formulation 
of pharmaceutical products. Once in the bloodstream, endotoxins can cause adverse effects such as fever, vasodilatation, diarrhea, blood coagulation, impaired liver functions and endocrine system, chills, headache, malaise, yawns and even death (Chen et al., 2009).

Endotoxins are relatively insensitive to $\mathrm{pH}$ changes and resistant to heat and bactericidal substances, making the sterilization of solutions, glassware and laboratory equipment very difficult. Endotoxin inactivation can be accomplished through different methods, including acidbase hydrolysis, dry heat sterilization, oxidation, ionization and complexation. These methods are predominantly used for equipment depyrogenation and are not suitable for use with labile or sensitive solutions (Petsch, Anspach, 2000).

Endotoxin removal methods include activated carbon adsorption, ion exchange, ultrafiltration and affinity chromatography. Activated carbon and ion exchange are not selective processes, removing several other components from the medium. Because charge density of endotoxins is not high, ion exchange results in low efficiency. Although ultrafiltration can be used, endotoxin agglomeration or complexation with other compounds in the medium hamper their selective removal. In addition, if both the product of interest and endotoxins are of similar size, the process efficiency is compromised.

Processes that exploit the phenomenon of selective adsorption, such as affinity chromatography and membrane adsorber processes, afford minor or zero loss of the product due to the specificity of the ligands. These processes can be used for endotoxin removal where the membrane adsorber process is particularly promising for this application due to its advantages over the affinity chromatography process (Petsch et al., 1997). In addition, the low compressibility of the chromatographic resins in affinity chromatography leads to a large pressure drop. Membrane adsorbers are able to treat higher feed flow than affinity chromatography since diffusion within the membrane pores is insignificant and hence mass transfer is governed by convection. Therefore, high flux can be obtained at moderate pressures, resulting in high productivity and low operation times.

The use of nylon for the preparation of membrane adsorbers results in a highly porous structure, providing large contact area for endotoxin adsorption; nylon's mechanic stability allows the adsorber to withstand high pressures; the availability of reactive groups, such as $\mathrm{OH}$, $\mathrm{NH}_{2}, \mathrm{SH}, \mathrm{COOH}$, is convenient for ligand immobilization; in addition, nylon exhibits thermal and chemical stability. Although poly(ethylene vinyl alcohol) (PEVA) membranes and cellulose acetate have also been used in some studies, these materials have some inconvenient properties: while PEVA exhibits non-specific binding, deacetylation of cellulose acetate is required to increase the number of reactive hydroxyl groups, which can modify membrane pore size distribution and reduce the material's mechanical stability (Petsch et al., 1998).

Different ligands have been proposed for the removal of endotoxins, such as polymyxin $\mathrm{B}$, histamine, histidine, protamine, poly(L-lysine), poly(ethylene imine), dimethylamine, deoxycholate and others, having moderate or high efficiency. These can be immobilized on agarose gels, cellulose spherical particles or on membranes of nylon, poly(vinyl alcohol) (PVA), PEVA or cellulose. The removal of endotoxins and other biomolecules using membrane adsorbers has been intensely investigated by Anspach et al. (Petsch, Anspach 2000; Petsch et al., 1997, 1998; Anspach, Petsch 2000; Anspach, 2001). The authors described the manufacture of a nylon membrane coated with dextran and functionalized with different ligands which offered greater endotoxin removal and higher productivity compared to functionalized Sepharose chromatographic sorbents (Petsch et al., 1997). In another study (Petsch et al., 1998), the performance of poly(ethyleneimine)immobilized adsorbers was evaluated. Poly(vinyl alcohol) and poly(ethylenevinyl alcohol) (PEVA) membranes and Sepharose were used as immobilization matrices, with the membranes proving the best adsorbers. However, non-specific endotoxin adsorption was observed for PEVA membranes.

Histamine, histidine and polymyxin B ligands are equally effective for removing endotoxins. The main drawback of polymyxin B is its neuro and nephrotoxicity, which can pose a problem in the event of release from the sorbent. Histamine exhibits biological activity which may also be problematic. Histidine, on the other hand, is a potential ligand for endotoxin removal due to its low cost and lack of toxicity. The structure of the histidine comprises the groups $-\mathrm{COOH},-\mathrm{NH}_{2}$ and has an imidazole ring as a lateral group, which contribute to hydrophobic or charge-induced interactions with biomolecules (Anspach, 2001; Acconci, 1998; Hanora et al., 2005; Wei et al., 2007).

In the present study, we report the preparation of an endotoxin adsorber based on histidine-modified nylon membranes, with an emphasis on adsorber preparation and the efficiency of the process in static mode for different initial concentrations of endotoxins. The coating of nylon with poly(vinyl alcohol) as a step of the immobilization strategy was explored to reduce non-specific adsorption, a technique not previously reported in the literature for histidine-containing nylon membrane adsorbers. 


\section{MATERIAL AND METHODS}

\section{Material}

Sodium borohydride, 1,4-butanediol diglycidyl ether (bisoxirane), L-histidine, poly(vinyl alcohol) (Mw 67,000), sodium periodate, hydrogen peroxide, Triton-X-100 and Purpald reagent were supplied by Sigma-Aldrich. Endotoxins. The Kinetic Chromogenic LAL assays were purchased from Lonza Cambrex (Brazil). Endotoxins were supplied as a lyophilized preparation of purified endotoxin from E. coli strain 055:B5. Ultrapure water was produced by a Millipore Rios/ MilliQ Synthesis system. All other chemicals were of analytical grade. Nylon 66 microporous flat-sheet membranes (Ultipor N 66 , nominal pore size of $0.45 \mu \mathrm{m}$, nominal diameter of $47 \mathrm{~mm}$ and thickness of $100 \mu \mathrm{m}$ of ) were used.

\section{Depyrogenation procedures}

All glassware was treated with $1.5 \mathrm{M} \mathrm{NaOH}$ and pyrogen-free water or by heat treatment at $180{ }^{\circ} \mathrm{C}$ for five hours. Plastics were treated with $33 \% \mathrm{H}_{2} \mathrm{O}_{2}$ solution and with pyrogen-free water followed by heat treatment at $80^{\circ} \mathrm{C}$ for eight hours (Zhang et al., 2007). Depyrogenation of the system and regeneration of the membranes were accomplished by circulating $0.1 \mathrm{M} \mathrm{NaOH}$ with $20 \%$ ethanol, pyrogen-free water and $1.5 \mathrm{M} \mathrm{NaCl}$ (Petsch et al., 1997).

\section{Membrane adsorber}

Preparation of the membrane adsorber entailed four steps: (1) first activation; (2) coating with PVA; (3) second activation; (4) ligand immobilization. Figure 1 depicts an illustration of the immobilization strategy. Figure 2 depicts the reactions involved in each immobilization step.

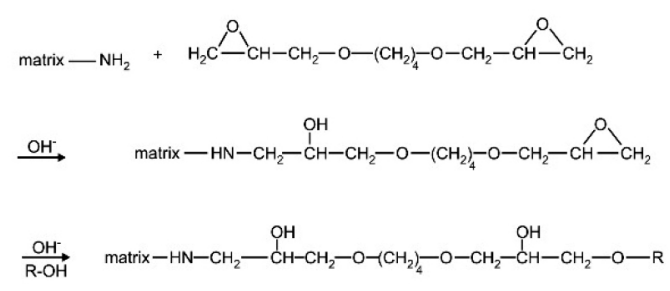

(a)

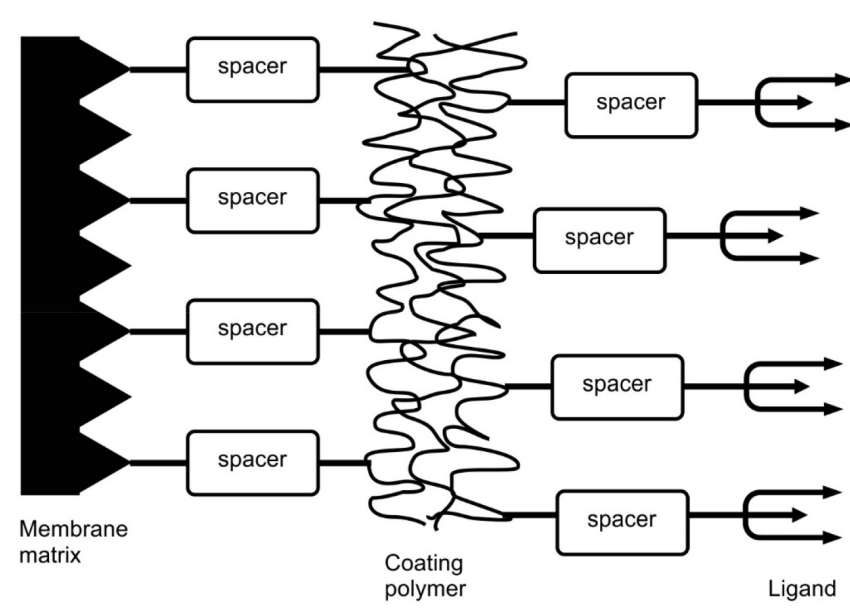

FIGURE 1 - Schematic representation of membrane adsorber structure.

In the first step (Figure 2(a)), bisoxirane (1,4-butanedioldiglycidyl ether) or formaldehyde are commonly used for membrane activation. Activation with bisoxirane occurs through nylon amine groups whereas activation with formaldehyde occurs through amide groups. Bisoxirane was chosen because it results in more robust and stable membranes than formaldehyde under alkaline and acid conditions (Beeskow, Kroner, Anspach, 1997).

For the second step, the polymers commonly used are dextran, PVA or hydroxyethylcellulose (HEC). Compared to PVA, dextran and HEC introduce a more irregular structure within the membrane. This irregular structure may cause tangling of the ligand and inactivate some binding sites. Thus, PVA was chosen as the polymer coating. Besides increasing the availability of reactive groups, PVA reduces non-specific adsorption.

To accomplish the third step, bisoxirane or epibromohydrin can be used as activators. Bisoxirane was selected since it is a larger molecule compared

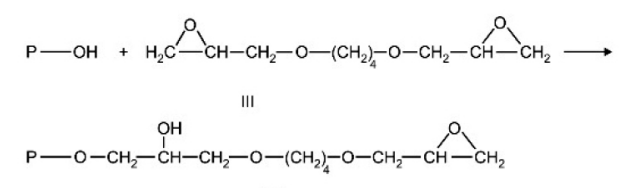

(b)

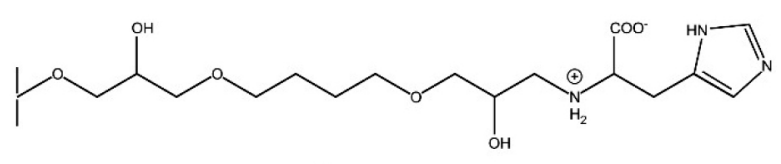

(c)

FIGURE 2 - Functionalization scheme: (a) Activation with bisoxirane through nylon amine group; (b) Second activation with bisoxirane, after surface treatment with PVA; (c) Histidine reaction with bisoxirane. 
to epibromohydrin and hence a more suitable spacer, providing better contact between the ligand (histidine) and the product (endotoxin) (Bueno, Haupt, Vijayalakshmi, 1995). The fourth step involves the reaction between histidine and bisoxirane (Figures 2(b) and 2(c)).

Membrane adsorbers were prepared as previously reported in the literature (Beeskow, Kusharyoto, Anspach, 1995; Castilho, Anspach, Deckwer, 2002; Castilho, Deckwer, Anspach, 2000; Lee, Tsai, 1999). Figure 3 shows the experimental apparatus. The first step was carried out by placing the membrane (nominal area of $13.4 \mathrm{~cm}^{2}$ ) in a dead-end cell and circulating a solution through the system containing $9 \mathrm{~mL}$ of bisoxirane, $1 \mathrm{~mL}$ of ethanol and $1 \mathrm{~mL}$ of $25 \mathrm{mM}$ sodium carbonate buffer ( $\mathrm{pH} 11)$ for 16 hours at $80^{\circ} \mathrm{C}$. The membrane was washed three times with water for 15 minutes per rinse, to avoid hydrolysis of the oxirane ring of bisoxirane. Immediately after washing, the membrane was incubated in an aqueous solution of $2 \%$ w/w PVA in $25 \mathrm{mM} \mathrm{Na}_{2} \mathrm{CO}_{3}$ buffer ( $\mathrm{pH} 11$ ) for 15 minutes at room temperature and for 14 hours at $100^{\circ} \mathrm{C}$. Excess PVA was removed by washing the membrane with $1 \%$ Triton-X-100 solution for 15 minutes, 3 times, followed by rinsing 3 times with water.

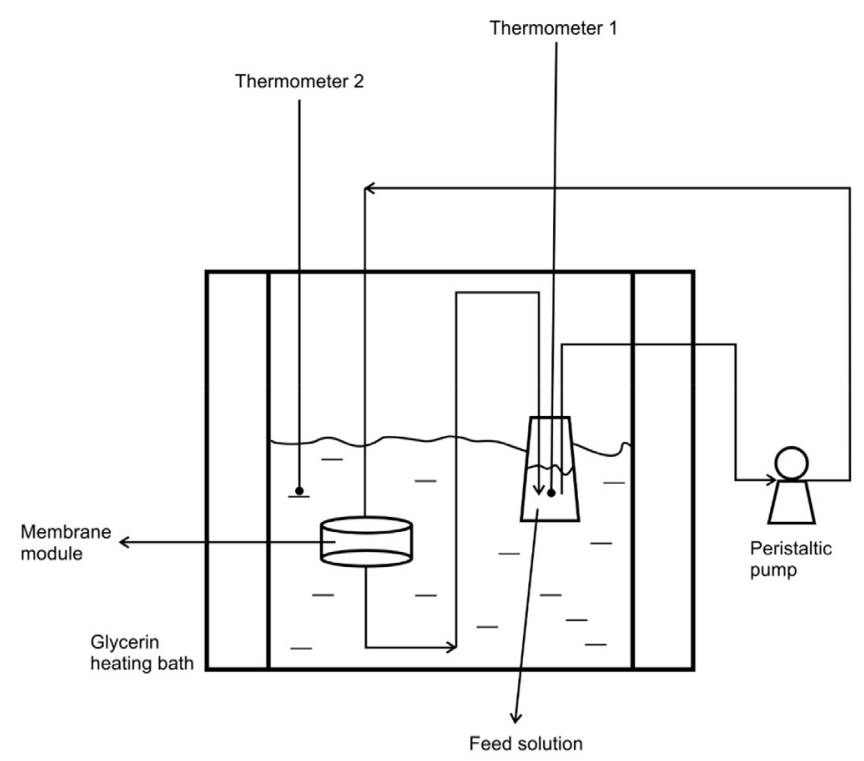

FIGURE 3 - Experimental apparatus for preparation of membrane adsorber.

The third and fourth steps were carried out according to Petsch et al., 1998. The procedure consisted of recirculating a solution of $50 \mathrm{mg}$ of sodium borohydride in $15 \mathrm{~mL}$ of $2 \mathrm{M} \mathrm{NaOH}, 25 \mathrm{~mL}$ of water and $5 \mathrm{~mL}$ of bisoxirane through the system for 3 hours at room temperature. Hydrolysis of the oxirane group of the bisoxirane was carried out by incubating the membrane in $\mathrm{HCl}$ solution ( $\mathrm{pH} 2.5$ ) for 30 minutes, followed by incubation at room temperature for 90 minutes in $0.2 \mathrm{M}$ sodium periodate solution. Immobilization of L-histidine was carried out by dissolving $0.5 \mathrm{~g}$ L-histidine in $10 \mathrm{~mL}$ of $0.5 \mathrm{M}$ sodium carbonate buffer ( $\mathrm{pH} 11)$ and passing this solution through the system at $75^{\circ} \mathrm{C}$ for 2 hours. Subsequently, the membrane was washed 3 times for 15 minutes per rinse, with $1 \mathrm{M} \mathrm{NaCl}$ and with water. Functionalized membranes were kept under refrigeration in $0.02 \% \mathrm{NaN}_{3}$ until further use.

\section{Endotoxin adsorption}

Adsorption experiments were carried out in static mode in $250 \mathrm{~mL}$ Hach flasks at $23^{\circ} \mathrm{C}$. The membrane was previously equilibrated with $20 \mathrm{mM}$ sodium phosphate buffer (pH 7.0) for 20 minutes. Endotoxin solution of known concentration, in the same buffer used for equilibrium, was placed in contact with the membranes for about 6 hours under stirring at room temperature. The endotoxin concentrations were determined by Kinetic Chromogenic LAL assay or the Purpald method. Samples were frozen to prevent microbial growth when not analyzed immediately after the experiment.

\section{Analytical method}

Endotoxin concentration was measured using a quantitative LAL assay (Kinectic-QCL method) (Chen et al., 2009), kindly performed by Oswaldo Cruz Foundation of Brazil (Fiocruz). In this assay, a sample containing endotoxin is mixed with LAL reagent (LAL Assay Kit, Lonza) and monitored over time by spectrophotometry for the appearance of a yellow color at $405 \mathrm{~nm}$.

Since the LAL assay is very expensive, the Purpald method (Lee, Tsai, 1999) was used when endotoxin concentration was above $75,000 \mathrm{EU} / \mathrm{mL}$. The determinations of the endotoxin concentrations by the Purpald method is based on the reaction between sodium periodate and the unsubstituted terminal vicinal glycol (UTVG) group, present in endotoxin structure, producing formaldehyde and oxidizing the LPS. Formaldehyde subsequently reacts with Purpald reagent yielding a colorless adduct, which is further oxidized by sodium periodate to form a purple end product, quantified by spectrophotometry at $550 \mathrm{~nm}$.

\section{Determination of ligand density $\left(D_{L}\right)$}

This procedure was carried out in duplicate, as described by Aquino (2000). Density of L-histidine ligand 
was determined by circulating a $0.05 \mathrm{M}$ copper sulfate solution through the membrane adsorber at $2 \mathrm{~mL} / \mathrm{min}$ for 2 hours at room temperature. The membrane adsorber was then washed with deionized water to remove excess copper, which was monitored by measuring the solution absorbance at $809 \mathrm{~nm}$, the wavelength of maximum copper absorption. In a second step, the same procedure was adopted using a $0.25 \mathrm{M}$ EDTA solution $\mathrm{pH} 7.0$ instead of the copper sulfate solution, and the quantity of copper released by the membrane was monitored by measuring the absorbance of the solution at $730 \mathrm{~nm}$ (wavelength of maximum absorption of EDTA-copper complex). The concentration of copper in the membrane adsorber was obtained from a calibration curve with copper dissolved in a solution of $0.25 \mathrm{M}$ EDTA pH 7.0. Copper and histidine form a 1:1 complex, hence the amount of copper binding the membrane adsorber is equivalent to the amount of immobilized histidine.

\section{RESULTS AND DISCUSSION}

\section{Efficiency of the depyrogenation processes}

The efficiency of depyrogenation of the materials, solutions and systems was evaluated using the LAL method for endotoxin detection. Four samples were analyzed. Sample 1 was ultrapure water. It was collected in a pyrogen-free plastic beaker and placed in a pyrogenfree glass vial. As shown in Table I, the low endotoxin concentration $(0.083 \mathrm{EU} / \mathrm{mL})$ indicates optimal water quality. Its value is well below the value accepted for injection water of $0.25 \mathrm{EU} / \mathrm{mL}$. This result confirms the depyrogenation procedures for plastics and glassware (heating to $180^{\circ} \mathrm{C}$ ) materials were adequate. Samples 2 and 3 were $0.2 \mathrm{M}$ monobasic sodium phosphate and dibasic sodium phosphate, respectively. Endotoxin concentrations were lower than the acceptable value of $1.10 \mathrm{EU} / \mathrm{mL}$ for these solutions, confirming that depyrogenation by treatment with $1.5 \mathrm{M} \mathrm{NaOH}$ was also effective. Sample 4 was ultrapure water after being circulated through the previously cleansed system. It indicated a concentration lower than $0.10 \mathrm{EU} / \mathrm{mL}$, below the accepted value for injection water. These results confirm the efficiency of the depyrogenation methods used.

\section{Evaluation of endotoxins removal by membrane adsorption}

The ligand density for the two membrane adsorbers was $7.38 \mathrm{mg} / \mathrm{g}$ and $6.30 \mathrm{mg} / \mathrm{g}$, higher than values reported in the literature (Petsch et al., 1997; Acconci, 1998; Aquino,
TABLE I - Evaluation of the depyrogenation procedures of the materials

\begin{tabular}{lc}
\hline Sample & $\begin{array}{c}\text { Endotoxin concentration } \\
(\mathbf{E U} / \mathbf{m L} \mathbf{L})\end{array}$ \\
\hline $\begin{array}{l}\text { 1.Ultrapure water } \\
\text { 2. Monobasic sodium phosphate }\end{array}$ & lower than 0.10 \\
3. Dibasic sodium phosphate & lower than 0.10 \\
$\begin{array}{l}\text { 4. Water circulated through the } \\
\text { system }\end{array}$ & lower than 0.10 \\
\hline
\end{tabular}

2000) indicating the great potential of the membrane adsorbers prepared. The membrane with highest ligand density was used in static adsorption experiments. Results are shown in Figure 4 and removal efficiency is given in Table II. This shows an endotoxins removal efficiency of up to $65 \%$. At higher initial endotoxin concentration, there is lower removal efficiency when equilibrium is achieved, as can be seen in Table II. These results also indicate that maximum adsorption capacity is achieved for an initial concentration of over 1,300,000 EU/mL.
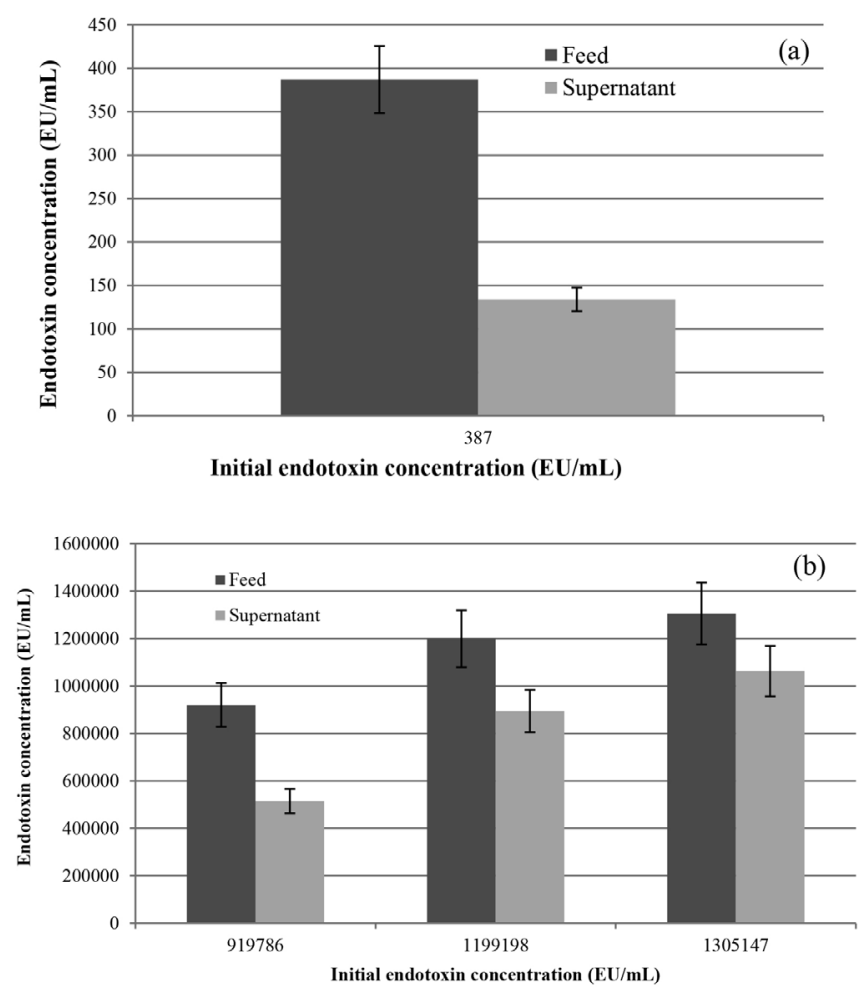

FIGURE 4 - Static adsorption test with membrane adsorber for: (a) low initial endotoxin concentration; and (b) high initial endotoxin concentrations.

Acconci (1998) used a membrane adsorber, with L-histidine as a ligand and PEVA as the membrane 
TABLE II - Membrane adsorber performance for different initial endotoxin concentrations

\begin{tabular}{lc}
\hline $\begin{array}{l}\text { Initial endotoxin } \\
\text { concentration }(\mathbf{E} \mathbf{U} / \mathbf{m L})\end{array}$ & Removal (\%) \\
\hline 387 & 65 \\
919,786 & 44 \\
$1,199,198$ & 25 \\
$1,305,147$ & 18 \\
\hline
\end{tabular}

material, to remove endotoxins from a sodium phosphate buffer solution whose ionic strength and $\mathrm{pH}$ were similar to those of the present study. The author achieved endotoxins removal of $29 \%$ for an initial concentration of $84 \mathrm{EU} / \mathrm{mL}$. Based on data from the present study, estimated removal was greater than $65 \%$ for the same initial concentration. This superior performance can be attributed to the higher histidine density obtained with the nylon support used in this study.

Petsch et al. (1997) used a membrane adsorber of nylon coated with dextran, instead of PVA, and histidine as the ligand. The results obtained by the authors showed endotoxin removal of approximately $69 \%$, using an initial endotoxin concentration of $6,000 \mathrm{EU} / \mathrm{mL}$ under the same conditions of ionic strength and $\mathrm{pH}$ as the present study. These removal rates are close to those obtained in the present study. Poly(ethyleneimine) (PEI) was also used as a ligand in another study (Petsch et al., 1998), with PVA as the coating polymer. Results were similar under the same conditions of ionic strength, $\mathrm{pH}$ and initial endotoxin concentration, suggesting that PVA and dextran can be used interchangeably as coating polymers.

Endotoxin adsorption on unmodified membrane does not take place, as shown in Figure 5(a). The nylon membrane exhibited no noticeable endotoxin adsorption. Adsorption on tubing and vessels, without the membrane, was also ruled out, as shown in Figure 5(b). These observations confirm that the adsorption of endotoxins by the membrane adsorber was due to interaction between negatively charged endotoxins and positively charged histidine at the membrane surface, as suggested in other studies (Petsch et al., 1997).

The stability of the membrane adsorber was evaluated based on measurements of ligand density during the adsorption experiments. The initial ligand density was $7.38 \mathrm{mg} / \mathrm{g}$ and the same ligand density was observed for around 30 months. After this period, ligand density decreased to $0.75 \mathrm{mg} / \mathrm{g}$ and no further endotoxin adsorption was observed.
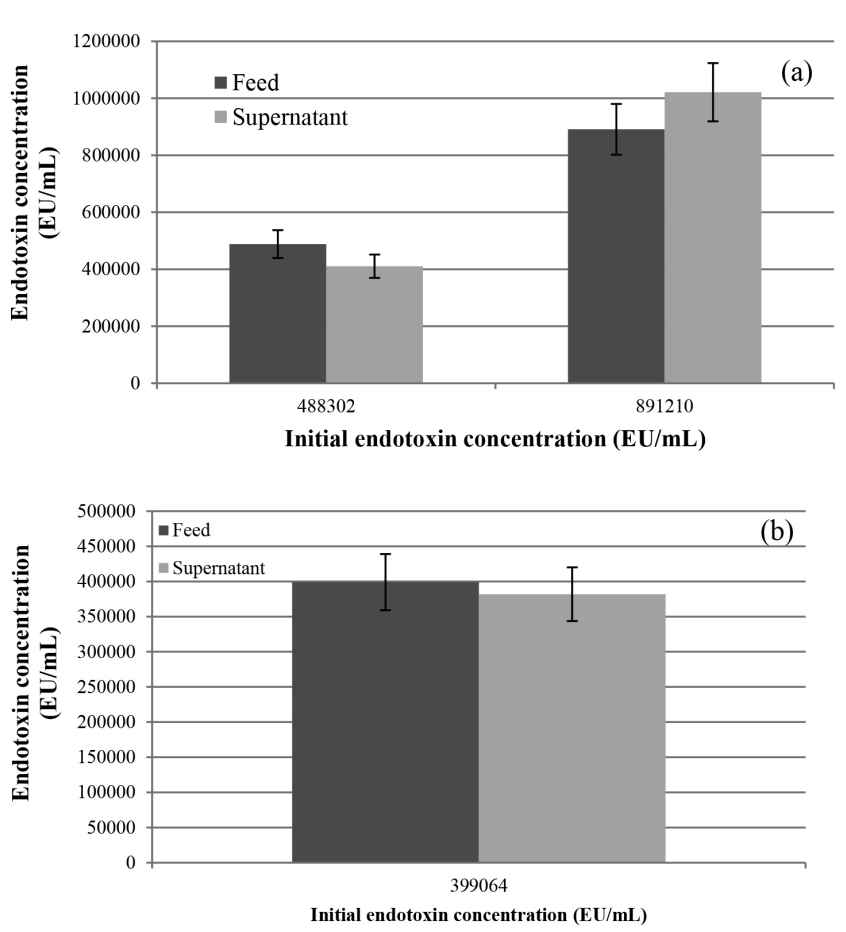

FIGURE 5 - Endotoxin adsorption: (a) on unmodified membrane; and (b) on system tubing and vessels.

\section{CONCLUSIONS}

In the present study, a membrane adsorber was successfully developed for the removal of endotoxins from aqueous solutions. Histidine was efficiently immobilized at the membrane surface, resulting in a ligand density of around $7 \mathrm{mg} / \mathrm{g}$. Static adsorption experiments indicated removal of up to $65 \%$ of the endotoxins in feed solution. This result was greater than values reported in the literature with the use of PEVA as membrane material. This greater removal most likely stems from the high histidine density obtained with the nylon support used in this study. No endotoxin adsorption onto unmodified membranes was observed, confirming that the binding of endotoxins was exclusively due to interaction between endotoxins and histidine. The membrane adsorbers were highly stable with a lifespan of approximately thirty months.

\section{ACKNOWLEDGMENTS}

The authors gratefully acknowledge Capes for research funding (Rede NANOBIOTEC-BRASIL 04/2008 and National Post-Doctoral Program PNPD) and the Laboratories of Membrane Separation Processes, Biotechnological Processes and Cell Culture Engineering of the Chemical Engineering Program, at the Federal University of Rio de Janeiro. 


\section{REFERENCES}

ACCONCI, C. Processo de remoção de endotoxinas de soros hiperimunes: filtração em membranas de afinidade. Campinas, 1998. 112 p. [Dissertation of Master Degree. University of Campinas].

ANSPACH, F.B.; PETSCH, D. Membrane adsorbers for selective endotoxin removal from protein solutions. Process Biochem., v.35, n.9, p.1005-1012, 2000.

ANSPACH, F.B. Endotoxin removal by affitnity sorbents. $J$. Biochem. Biophys. Meth., v.49, n.1/3, p.665-681, 2001.

AQUINO, L.C.L. Adsorção de IgG humana em duas matrizes porosas derivatizadas com o ligante histidina. Campinas, 2000. 99 p. [Dissertation of Master Degree. University of Campinas].

BEESKOW, T.C.W.; KUSHARYOTO, W.; ANSPACH, F.B. Surface modification of microporous polyamide membranes with hydroxyethyl cellulose and their application as affinity membranes. J. Chromatogr. A, v.715, n.1, p.49-65, 1995.

BEESKOW, T.C.; KRONER, K.H.; ANSPACH, F.B. Nylonbased affinity membranes: impacts of surface modification on protein adsorption. J. Colloid Interf. Sci., v.196, n.2, p.278-291, 1997.

BUENO, S.M.A.; HAUPT, K.; VIJAYALAKSHMI, M.A. Separation of immunoglobulin $\mathrm{G}$ from human serum by pseudobioaffinity chromatography using immobilized L-histidine in hollow fibre membranes. J. Chromatogr. B, v.667, n.1, p.57-67, 1995.

CASTILHO, L.R.; DECKWER, W.; ANSPACH, F.B. Influence of matrix activation and polymer coating on the purification of human IgG with protein A affinity membranes. $J$. Membrane Sci., v.172, n.1/2, p.269-277, 2000.

CASTILHO, L.R.; ANSPACH, F.B.; DECKWER, W. Comparison of affinity membranes for the purification of immunoglobulins. J. Membrane Sci., v.207, n.2, p.253-264, 2002.
CHEN, R.H.; HUANG, C.J.; NEWTON. B.S.; RITTER, G.; OLD, L.J.; BATT, C.A. Factors affecting endotoxin removal from recombinant therapeutic proteins by anion exchange chromatography. Protein Expres. Purif., v.64, n.1, p.76-81, 2009.

HANORA, A.; PLIEVA, F.M.; HEDSTRÖM, M.; GALAEV, I.Y.; MATTIASSON, B. Capture of bacterial endotoxins using a supermacroporous monolithic matrix with immobilized polyethyleneimine, lysozyme or polymyxin B. J. Biotechnol., v.118, n.4, p.421-433, 2005.

LEE, C.; TSAI, C. Quantification of bacterial lipopolysaccharides by the purpald assay: measuring formaldehyde generated from 2-keto-3-deoxyoctonate and heptose at the inner core by periodate oxidation. Anal. Biochem., v.267, n.1, p.161$168,1999$.

PETSCH, D.; BEESKOW, T.C.; ANSPACH, F.B.; DECKWER, W. Membrane adsorbers for selective removal of bacterial endotoxin. J. Chromatogr. B: Biomed. Sci. Appl., v.693, n.1, p.79-91, 1997.

PETSCH, D.; DECKWER, W.; ANSPACH, F.B.; LEGALLAIS, C.; VIJAYALAKSHMI, M. Endotoxin removal with poly(ethyleneimine)-immobilized adsorbers: sepharose $4 \mathrm{~B}$ versus flat sheet and hollow fibre membranes. $J$. Chromatogr. B, v.707, n.1/2, p.121-130, 1998.

PETSCH, D.; ANSPACH, F.B. Endotoxin removal from protein solutions. J. Biotechnol., v.76, n.2/3, p.97-119, 2000.

WEI, Z.; HUANG, W.; LI, J.; HOU, G.; FANG, J.; YUAN, Z. Studies on endotoxin removal mechanism of adsorbents with amino acid ligands. J. Chromatogr. B: Analyt. Technol. Biomed. Life Sci., v.852, n.1/2, p.288-292, 2007.

ZHANG, Y.; YANG, H.; ZHOU, K.; PING, Z. Synthesis of an affinity adsorbent based on silica gel and its application in endotoxin removal. React. Funct. Polym., v.67, n.8, p.728$736,2007$.

Received for publication on $17^{\text {th }}$ December 2014 Accepted for publication on $23^{\text {rd }}$ July 2015 
